\title{
Acute tissue death (white syndrome) affects the microenvironment of tabular Acropora corals
}

\author{
S. B. Andersen ${ }^{1,5, *}$, M. L. Vestergaard ${ }^{1}$, T. D. Ainsworth ${ }^{2}$, O. Hoegh-Guldberg ${ }^{3}$, \\ M. Kühl ${ }^{1,4}$ \\ ${ }^{1}$ Marine Biological Laboratory, Department of Biology, University of Copenhagen, Strandpromenaden 5, 3000 Helsingør, \\ Denmark \\ ${ }^{2}$ ARC Centre of Excellence for Coral Reef Studies, James Cook University, Townsville, Queensland 4811, Australia \\ ${ }^{3}$ Centre for Marine Studies, University of Queensland, Brisbane, Queensland 4072, Australia \\ ${ }^{4}$ Plant Functional Biology and Climate Change Cluster, University of Technology Sydney, PO Box 123, Ultimo, Sydney, \\ NSW 2007, Australia \\ ${ }^{5}$ Present address: Centre for Social Evolution, Department of Biology, University of Copenhagen, \\ Universitetsparken 15 Building 12, 2100 Copenhagen, Denmark
}

\begin{abstract}
White syndrome (WS) is a collective term for coral diseases that cause acute tissue loss, resulting in apparently healthy tissue bordering on exposed skeleton. In this study, the microenvironmental condition and tissue structure of WS-affected tabular acroporid corals were assessed by $\mathrm{O}_{2}$ microelectrodes and histological techniques. The high spatial resolution of the microelectrode measurements enabled an evaluation of the extent of physiological changes at, and $2 \mathrm{~cm}$ away from, the WS border. Respiration of the coral host was decreased on the skeleton-tissue border but was comparable to that of healthy corals only $2 \mathrm{~cm}$ away from the border. Histological data, however, showed a decrease in mesogloea thickness on and $2 \mathrm{~cm}$ away from the WS border, which correlates with a previously observed allocation of photoassimilates away from the WS border. We suggest that there are colony-wide negative effects of WS which affect only the host physiology and, as disparate etiologies are evident in WS, these must be distinguished through the utilization of a multiple tool approach.
\end{abstract}

KEY WORDS: Coral disease $\cdot$ White syndrome $\cdot$ Microelectrode $\cdot$ Histology

Resale or republication not permitted without written consent of the publisher

\section{INTRODUCTION}

The symbiotic relationship between corals and photosynthetic dinoflagellates (zooxanthellae) of the genus Symbiodinium provides the framework for the highly diverse and productive coral reefs, together with a consortium of microorganisms (Muscatine 1990, Rosenberg et al. 2007). Degradation of these important ecosystems has rapidly advanced the research on coral pathology since the 1970s. Numerous diseases causing coral damage and colony mortality are now recognised, but in the majority of cases no causative agents have been identified and the disease mechanisms remain poorly understood. Additionally, much confusion arises in the naming of diseases (Richardson 1998, Ainsworth et al. 2007b, Rosenberg et al. 2007).
The term white syndrome (WS) is used collectively to refer to any disease or diseases causing acute tissue loss, leaving the white skeleton exposed, and is found to affect multiple coral species (Willis et al. 2004). WS affecting tabular acroporid corals from the Great Barrier Reef is a relatively well-characterized disease (Roff et al. 2006, Work \& Aeby 2006, Ainsworth et al. 2007a). In these WS-affected corals, apparently healthy tissue borders a clear line of exposed skeleton, and tissue loss from the coral colony is acute, reaching rates of $>400 \mathrm{~cm}^{2} \mathrm{wk}^{-1}$ (Roff et al. 2006). The zooxanthellae are photo competent at the skeleton-tissue border, indicating that the acute tissue loss associated with the syndrome does not progress through, or is associated with, endosymbiont loss or coral bleaching (Roff et al. 2008). Metabolites are directed away from the WS bor- 
der; in contrast, when mechanical damage is inflicted on healthy corals, photoassimilates are translocated towards the lesion for tissue regeneration (Roff et al. 2006). The main cause of cell death in the coral host is apoptosis (Ainsworth et al. 2007a), indicating that WS is similar to previously described 'shut-down' reactions of the coral host (Antonius 1977). Apoptosis is a controlled way of eliminating cells with minimal damage to surrounding tissues. This process is important in the normal development of organisms, in addition to being a mechanism for removing damaged or malfunctioning cells and infectious agents (Ameisen 2002). Apoptosis is also a main cause of death of the zooxanthellae in thermally induced bleached corals, while the host tissues are left relatively unaffected (Strychar et al. 2004, Strychar \& Sammarco 2009). Bacterial colonization in tissues of these WS-affected corals was not observed by Ainsworth et al. (2007a). In contrast, Sussman et al. (2008) identified Vibrio bacteria as the possible causative agent for WS affecting tabular acroporids and other species. However, their lab-infected corals experienced visually identifiable bleaching across the coral colony prior to tissue loss, which is inconsistent with the previously observed characteristics of WS progression on tabular acroporids in the field (Roff et al. 2006, 2008).

The present study compared the microenvironment of the WS border and visually healthy tissue $2 \mathrm{~cm}$ away from the border with that of unaffected healthy corals using $\mathrm{O}_{2}$ microelectrode measurements of respiration. Respiration is a potentially useful parameter for characterizing and differentiating cell or tissue states associated with similar coral diseases. Under physiologically stressful conditions, coral respiration may either increase, e.g. under temperature stress (Nii \& Muscatine 1997, Edmunds 2005) or peat pollution (Dallmeyer et al. 1982), or decrease, e.g. with changes in salinity (Muthiga \& Szmant 1987). In apoptotic cells, a decrease in respiration is typically observed, as mitochondria are targeted early in programmed cell death pathways (Ameisen 2002). Measuring coral respiration of WS-affected tissue may thus provide information on the processes occurring in diseased individuals and the extent of physiological change to the entire coral colony disparate from the actual disease site. Microelectrodes are the ideal tool for this purpose, as they provide highly localized measurements with minimal disturbance at a high spatial resolution. This allows for measurements exactly on the skeleton-tissue border. The tissue on the WS border appears healthy visually, in that no bleaching or tissue disruption is evident. We aimed to determine whether respiration is reduced, due to apoptosis of the host cells, or increased, due to bacterial colonisation and respiration. By comparing the respiration at the WS border with the respi- ration $2 \mathrm{~cm}$ away from the border, in conjunction with histological investigation of the host, we also aimed to determine if it is possible to infer disease progression within the colony.

\section{MATERIALS AND METHODS}

Experimental design and analysis. The study was performed at Heron Island, Great Barrier Reef $\left(23.4417^{\circ} \mathrm{S}, 151.9125^{\circ} \mathrm{E}\right)$, Australia, in May and June 2006, using tabular Acropora spp. coral fragments (A. clathrata, A. cytherea and A. hyacinthus, not further identified) collected by SCUBA diving from 4 to $8 \mathrm{~m}$ depth. The corals were kept in shaded outdoor aquaria with a continuous supply of aerated seawater from the reef flat at temperatures of 20 to $26^{\circ} \mathrm{C}$ and a salinity of 20 to 22 ppt. Measurements of respiration were conducted within 1 to $3 \mathrm{~d}$ of collection, in a flow chamber $(10 \times 8 \times 19 \mathrm{~cm})$ connected to an aerated water reservoir in a darkened laboratory. The flow was $5.5 \mathrm{~cm} \mathrm{~s}^{-1}$. Under a stereomicroscope the WS border was clearly discernible with bare skeleton bordering apparently healthy tissue. The respiration measurements were taken at this location and $2 \mathrm{~cm}$ away on diseased coral colonies ( $\mathrm{n}=5$ colonies, one measurement on each location). As WS develops in a characteristic and predictable way, moving from the centre of the coral towards the tips, it was possible to perform the measurements on the healthy corals in morphologically similar locations as on the diseased corals, to control for intracolonial differences in coral respiration $(n=6$ colonies).

Respiration of coral host tissues of WS-affected and healthy corals. Oxygen concentration was determined with Clark-type $\mathrm{O}_{2}$ microelectrodes (Revsbech \& Jørgensen 1986) connected to a picoamperemeter (PA2000, Unisense). Signals were recorded on a stripchart recorder (Servogor 110, Goerz-Metrawatt). The $\mathrm{O}_{2}$ microelectrodes had a measuring tip diameter of 10 to $20 \mu \mathrm{m}$, a $t_{90}$ response time of $<0.5 \mathrm{~s}$ and a stirring sensitivity of $<1$ to $2 \%$. Measurements were done at a spatial resolution of 50 to $100 \mu \mathrm{m}$. The microsensors were positioned manually with a micromanipulator (MM33, Märtzhäuser) mounted on a rack at a $45^{\circ}$ angle relative to the water surface. Vertical positioning of the microsensor measuring tip towards the coral tissue surface was monitored under a dissection microscope (Fig. 1a). The $\mathrm{O}_{2}$ microelectrode readings were linearly calibrated by reading the signal in air-saturated water and in an anoxic $\mathrm{Na}_{2} \mathrm{~S}_{2} \mathrm{O}_{4}$ solution, while the salinity was determined with a calibrated refractometer. Oxygen concentration in saturated seawater at experimental temperature and salinity was determined from tabulated values (www.unisense.com). 


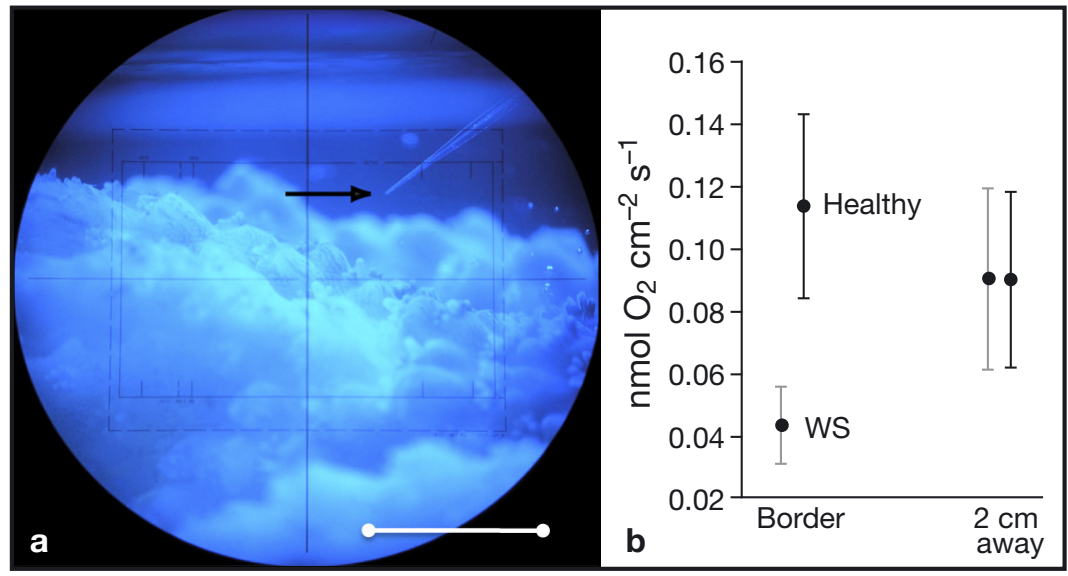

Fig. 1. Acropora spp. Microsensor measurements of coral respiration. (a) Tip of an $\mathrm{O}_{2}$ microelectrode (arrow) after measurement of dark respiration profile on healthy coral tissue. Scale bar $5 \mathrm{~mm}$ (Photo: G. Roff). (b) Dark respiration of white syndrome-affected corals measured on the WS border and $2 \mathrm{~cm}$ away $(\mathrm{n}=5)$ and on similar locations on healthy corals $(n=6$; mean $\pm \mathrm{SE})$

After 30 min of dark-adaptation, total respiration was determined by measuring $\mathrm{O}_{2}$ concentration microprofiles from the tissue surface and $2 \mathrm{~mm}$ into the water column. The signal was read every $0.05 \mathrm{~mm}$ for the first $0.5 \mathrm{~mm}$, and then every $0.1 \mathrm{~mm}$. The areal respiration rate was calculated as the local oxygen flux, $J$, using Fick's first law of diffusion (Revsbech \& Jørgensen 1986):

$$
J=\frac{D_{0}}{\delta_{E}}\left(C_{\infty}-C_{0}\right)
$$

where $D_{0}$ is the molecular diffusion coefficient at experimental temperature and salinity $\left(2.01 \times 10^{-5}\right.$ to $\left.2.36 \times 10^{-5} \mathrm{~cm}^{2} \mathrm{~s}^{-1}\right), \delta_{\mathrm{E}}$, is the effective thickness of the diffusive boundary layer (DBL), $C_{\infty}$ is the constant $\mathrm{O}_{2}$ concentration in the turbulent water phase and $C_{0}$ is the $\mathrm{O}_{2}$ concentration measured at the coral tissue surface. In darkness, the $\mathrm{O}_{2}$ supply is limited by the flux across the DBL causing anoxia inside the tissue (Kühl et al. 1995). The $\mathrm{O}_{2}$ flux is therefore a good estimate of the total tissue respiration rate.

Tissue analysis. The coral fragments used in the respiration measurements were fixed in $4 \%$ paraformaldehyde for $12 \mathrm{~h}$ and then stored in autoclaved phosphate buffered saline $\left(\mathrm{PBS}_{;} \mathrm{n}=5\right.$ colonies of both healthy and WS-affected individuals); 3 branches, sized 0.5 to $1 \mathrm{~cm}^{3}$, were removed from the fixed corals at the WS border, and $2 \mathrm{~cm}$ away (WS affected corals) and randomly (healthy corals).

Then, 2 of these branches from each WS border, $2 \mathrm{~cm}$ from the border, and healthy coral sample were used to determine zooxanthellae density ( $\mathrm{n}=5$ colonies of both healthy and WS-affected individuals). The tissue was airbrushed off the skeleton into a zip-lock bag, washed, centrifuged and the precipitate resuspended in $1 \mathrm{ml}$ PBS and then further diluted 1:200 in PBS. Zooxanthellae density was determined from this suspension by counting algae in a counting chamber under a microscope in 10 randomly chosen squares corresponding to $10 \mu \mathrm{l}$. The surface area from where the tissue originated was determined by the paraffin method as described in Stimson \& Kinzie (1991).

One branch from each WS border, 2 $\mathrm{cm}$ from the border and healthy coral sample was prepared for histology ( $n=4$ colonies of both healthy and WS-affected individuals) by decalcification in $32 \% \mathrm{HCl}$ for $4 \mathrm{~h}$, followed by paraffin embedding of the tissue using standard procedures. The embedded branches were cross-sectioned with a microtome $(6 \mu \mathrm{m}$ thin sections collected), mounted on slides and dried at $37^{\circ} \mathrm{C}$ for $24 \mathrm{~h}$ before deparaffinization and staining with the Masson Trichrome stain (www.ihcworld.com). The thickness of the gastroderm, mesogloea and epiderm was measured on 2 disparate tissue sections of each coral branch, using a compound microscope equipped with a calibrated scale in the field of vision. Within each section, the tissue layers were measured 3 times at different locations. All measurements were conducted on coenosarc tissue.

Statistics. Statistical analysis of the data was performed in SPSS 11.0.4 for Mac OSX (SPSS). With relatively small sample sizes ranging from 4 to 6 , non-parametric tests were used to compare data. The Wilcoxon signed rank test was used to compare measurements from within the same colony while the Mann-Whitney $U$-test was used to compare measurements between colonies.

\section{RESULTS}

\section{Dark respiration and zooxanthellae}

We found no gradient in dark respiration along the branch in healthy corals (Wilcoxon signed rank test: $Z=-0.73, \mathrm{n}=6, \mathrm{p}=0.46)$. There was also no significant difference evident in the respiration of healthy coral colonies and the tissues of coral colonies $2 \mathrm{~cm}$ away from the WS border (Mann-Whitney $U$-test, $U=23.0$, $\mathrm{n}=5$ and $6, \mathrm{p}=0.46)$. Significantly lower respiration was evident at the skeleton-tissue border of the WSaffected corals when compared to the tissues $2 \mathrm{~cm}$ away from the border, with a $52 \%$ mean reduction (Wilcoxon signed rank test: $Z=-2.02, \mathrm{n}=5, \mathrm{p} \leq 0.05$ ). 
Table 1. Acropora spp. Zooxanthellae density, dark respiration and thickness of coral tissue (mean $\pm \mathrm{SE} ; \mathrm{n}=5$ colonies for zooxanthellae counts, 5 and 6 for dark respiration measurements and 4 for tissue thickness measurements). Groupings in non-parametric tests are indicated by superscript. WS: white syndrome

\begin{tabular}{|llccrrr|}
\hline Coral & Location & $\begin{array}{c}\text { Zooxanthellae } \\
\left(10^{3} \mathrm{~cm}^{-2}\right)\end{array}$ & $\begin{array}{c}\text { Dark respiration } \\
\left(\mathrm{nmol} \mathrm{O} \mathrm{cm}^{-2} \mathrm{~s}^{-1}\right)\end{array}$ & $\begin{array}{c}\text { Endoderm } \\
(\mu \mathrm{m})\end{array}$ & $\begin{array}{c}\text { Mesoderm } \\
(\mu \mathrm{m})\end{array}$ & $\begin{array}{c}\text { Exoderm } \\
(\mu \mathrm{m})\end{array}$ \\
\hline WS & Border & $490 \pm 74^{\mathrm{A}}$ & $0.0433 \pm 0.0124^{\mathrm{A}}$ & $86 \pm 5.6^{\mathrm{A}}$ & $8.6 \pm 0.57^{\mathrm{A}}$ & $143 \pm 20^{\mathrm{A}}$ \\
& 2 cm away & $785 \pm 167^{\mathrm{AB}}$ & $0.0903 \pm 0.0291^{\mathrm{B}}$ & $101 \pm 8.8^{\mathrm{A}}$ & $12.5 \pm 1.2^{\mathrm{A}}$ & $147 \pm 20^{\mathrm{A}}$ \\
Healthy & Border & $838 \pm 168^{\mathrm{B}}$ & $0.114 \pm 0.0295^{\mathrm{B}}$ & $110 \pm 10^{\mathrm{A}}$ & $17.2 \pm 0.59^{\mathrm{B}}$ & $160 \pm 10^{\mathrm{A}}$ \\
& 2 cm away & & $0.0900 \pm 0.0116^{\mathrm{B}}$ & & \\
\hline
\end{tabular}

Respiration was also significantly lower on the WS border than on tissues of healthy coral colonies (MannWhitney $U$-test, $U=23.0, \mathrm{n}=5$ and $6, \mathrm{p} \leq 0.05$; Fig. $1 \mathrm{~b}$, Table 1).

Comparatively, there was also no significant difference between zooxanthellae density of healthy coral colony tissues and $2 \mathrm{~cm}$ from the WS border (MannWhitney $U$-test, $U=11.0, \mathrm{n}=5$ and $6, \mathrm{p}=0.75$ ). Nor was there a significant difference in symbiont density of the WS border and the tissues $2 \mathrm{~cm}$ away (Wilcoxon signed rank test: $Z=-0.944, \mathrm{n}=5, \mathrm{p}=0.35$ ). There was, however, a significantly lower density at the WS border when compared to the tissues of healthy coral colonies (Mann-Whitney $U$-test, $U=3.0, \mathrm{n}=5$ and 6 , $\mathrm{p} \leq 0.05$; Table 1).

\section{Tissue analysis}

While there were no significant differences in tissue thickness between the WS border and the tissues $2 \mathrm{~cm}$ away (Wilcoxon signed rank test: gastroderm: $Z=-1.46$, $\mathrm{p}=0.14$, mesogloea: $Z=-1.84, \mathrm{p}=0.07$, epiderm: $Z=$ $-0.73, \mathrm{p}=0.47 ; \mathrm{n}=4$ for all), the mesogloea was significantly thinner on the WS border, compared to healthy corals (Mann-Whitney $U$-test, gastroderm: $U=2, \mathrm{p}=$ 0.08; mesogloea: $U=0.0, \mathrm{p} \leq 0.05$, epiderm: $U=6, \mathrm{p}=$ $0.56 ; \mathrm{n}=4$ for all). Also, the mesogloea $2 \mathrm{~cm}$ away from the disease border was significantly thinner than in healthy coral colony tissues (Mann-Whitney $U$-test, gastroderm: $U=7, \mathrm{p}=0.89$; mesogloea: $U=0.5, \mathrm{p} \leq 0.05$, epiderm: $U=6, \mathrm{p}=0.69 ; \mathrm{n}=4$ for all; Fig. 2, Table 1).

\section{DISCUSSION}

We showed that coral physiological changes, as a result of disease, significantly affect not only the polyps at the site of the disease, but also the adjacent, apparently healthy tissues, high-lighting the importance of considering whole-colony consequences in the study of coral diseases.

Respiration was measured at the tissue surface of the coral colony and represents the sum respiration of the coral host, the zooxanthellae and the coral-associated microbes. In the present study, the dark respiration of WS-affected coral colonies was significantly lower at the WS skeleton-tissue border when compared to the tissues $2 \mathrm{~cm}$ away from the border and to that of healthy coral colonies. Alterations to tissue respiration, both increased and decreased, can be the result of many processes occurring within the coral holobiont, including morphological variability, metabolic changes, changes to the bacterial community and altered dinoflagellate density. We suggest that the lowered respiration in WS is a consequence of the acute tissue loss associated with some cases of WS in tabular Acropora.

In branching Acropora palmata corals, higher respiration is evident at the fast-growing branch tip compared to at the branch base (Gladfelter et al. 1989). The present study found that there was no difference in dark respiration between the points of measurement in the healthy tabular corals. The morphology of tabular acroporid corals, where the entire surface of the coral 'table' is made up of growing tips, results in a very different growth pattern to that found in branching corals. Hence respiration was measured on polyps at a similar distance to the main (base) branch. This morphology, in combination with the closeness of the
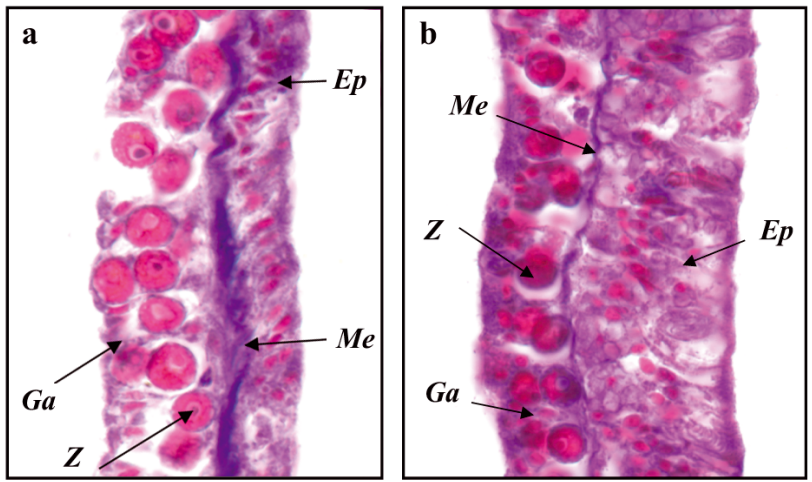

Fig. 2. Acropora spp. Tissue composition of healthy and white syndrome (WS)-affected corals. (a) Healthy tissue with gastroderm $(\mathrm{Ga})$, epiderm (Ep) and normal mesogloea (Me) thickness. (b) WS coral tissue from the tissue-skeleton border, where mesogloea thickness is significantly reduced but zooxanthellae (Z) are still present 
points of measurement, minimizes differences in the growth phase that could affect respiration. Therefore, variations in respiration found between diseased and healthy corals in the present study cannot be attributed to normal metabolic gradients, as occur in branching corals. Bacterial respiration also contributes to the total respiration measured on the coral surface. Using histopathological techniques, the microbiota of the WS border have previously been found not to differ from those of healthy corals (Ainsworth et al. 2007a). However, Sussman et al. (2008) found an increased abundance of Vibrio spp. bacteria in other cases of WS, using isolation and PCR-based screening. The microbial association at the WS border was not directly examined in the present study and it is thus not possible to directly interpret the role of bacterial respiration or its effect on the measured respiration. Based on the above-mentioned results, the contribution of bacterial respiration to the measured respiration should be either be the same on the WS border as in healthy tissue or higher, due to a proliferation of the bacterial population associated with the disease. However, the present study identified a $52 \%$ reduction in mean respiration at the WS border. A proliferation of apoptosis associated with acute tissue death can result in lowered tissue respiration.

Apoptosis is the predominant cause of cell death in WS of tabular acroporids (Ainsworth et al. 2007a). Cnidarians have a complex consortium of genes involved in apoptosis (Zmasek et al. 2007), one pathway of which is the Bax/Bcl-2 (Ainsworth et al. 2008) control of mitochondrial outer membrane permeability. The function of Bax genes has been relatively well characterised in mammals and shown to control the release of cytochrome $c$ from mitochondria. The permeability of the mitochondria triggers a shift in mitochondrial electron flow and results in the generation of reactive oxygen species and lowered respiration (Cai \& Jones 1998). It is likely that the proliferation of apoptosis at the WS border alters the metabolic capacity of the host and significantly lowers respiration. A decrease in symbiont number (as found in the present study) may also partly explain the lowered respiration at the WS border. However, zooxanthellae respiration has been estimated to account for only ca. $19 \%$ of the total respiration in the coral Pocillopora eydoxi with a comparable density of symbionts (mean density = $6.066 \times 10^{5}$ zooxanthellae $\mathrm{cm}^{2}$; Davies 1984). The decrease in the number of symbionts at the WS border is thus unlikely to be the sole cause of the lowered respiration, indicating that the lowered respiration on the WS border is primarily caused by a substantial change in host metabolism. Furthermore, the significant difference in respiration across a distance of only $2 \mathrm{~cm}$ from the WS border confirms the apparently healthy or 'normal' metabolic state of tissue in close proximity to the progressive disease zone. However, this result highlights the difficultly in relying on a single parameter to define normal or healthy status in the coral holobiont.

Tissue layer thickness was significantly different in healthy corals compared to WS-affected corals. The mesoglea was thinner in tissues both at the WS border and $2 \mathrm{~cm}$ away from the border. The mesogloea is an extracellular matrix that is reported to be important for the intra-colony transport of metabolites and amoebocytes, which are central for the coral immune response (Mullen et al. 2004). The observed reduction in mesogloea thickness could be caused by either lower excretion of the extracellular components that make up the mesogloea, possibly as a consequence of the high degree of apoptotic cells, or alternatively a breakdown of the existing matrix due to a lack of photoassimilate translocation. While the mesogloea is presumably essential for the internal distribution of resources within the coral holobiont, it presents a barrier to the diffusion of $\mathrm{O}_{2}$ and carbohydrates from the epiderm to the gastroderm (Chapman \& Pardy 1972, Brafield \& Chapman 1983). A thinner mesogloea might increase the solute transfer between these tissue layers. In contrast, it would be expected that the lateral distribution of metabolites is slowed by a reduction of the mesogloea, which may explain the lack of allocation of photoassimilates towards the WS border as observed by Roff et al. (2006). The responses of the mesoglea have not been investigated in any other study of coral health and disease, and it is therefore not yet possible to determine if this alteration to one of the host tissue layers is a cause or consequence of disease.

Finally, in a previous study no change in zooxanthellae density was found in WS-affected corals, when compared to healthy, unaffected coral colonies (Roff et al. 2008). In the present study, no visual evidence (whitening of the tissues) was apparent in WS corals. The symbiont density was not significantly different within the tissues of the WS corals or between the tissues $2 \mathrm{~cm}$ away from the border and that of healthy corals. However, there was a significant difference in zooxanthellae density in the tissues directly adjacent to the WS border when compared to healthy coral colonies (Table 1). This shows that symbiont loss associated with acute tissue loss in tabular WS is restricted to the tissues at the border. In the cases of bacterial induced WS as described by Sussman et al. (2008), symbiont loss was determined by visually identifiable whitening of the host tissues across large areas of the entire host colony. These disparate results provide substantial evidence that WS diseases manifest different disease etiologies, and these may represent very different diseases. 
The cause, or causes, of WS in tabular acroporids and the potential involvement of bacteria in how the disease manifests in the wild is yet to be determined. The present study demonstrated localized metabolic change occurring in WS-affected corals compared to more widespread changes in tissue composition, and confirmed that $\mathrm{O}_{2}$ microelectrodes in combination with traditional pathological tools may be a useful means to determine disease effects at a high spatial resolution in corals. Further studies are needed to elucidate the cause and effect of reductions to the mesogloea, and to better understand the composition of this layer and its role in corals. It is imperative to utilise a suite of tools when investigating the cause of disease and colony mortality in corals. Microelectrode studies can improve our understanding of the effects of coral diseases, and further investigation of host metabolism, as a measure of health, will improve our understanding of coral diseases.

Acknowledgements. This study was supported by the Danish Natural Science Research Council (M.K.), Oticon Fonden, Frimodt-Heineke Fonden (S.B.A.) and Johan Ernst Nyrop's Mindefond (M.L.V.). We thank the staff on Heron Island Research Station for excellent technical support and G. Roff for valuable comments.

\section{LITERATURE CITED}

Ainsworth T, Kvennefors E, Blackall L, Fine M, HoeghGuldberg O (2007a) Disease and cell death in white syndrome of acroporid corals on the Great Barrier Reef. Mar Biol 151:19-29

Ainsworth TD, Kramasky-Winter E, Loya Y, Hoegh-Guldberg O, Fine M (2007b) Coral disease diagnostics: What's between a plague and a band? Appl Environ Microbiol 73:981-992

Ainsworth TD, Hoegh-Guldberg O, Heron SF, Skirving WJ, Leggat W (2008) Early cellular changes are indicators of pre-bleaching thermal stress in the coral host. J Exp Mar Biol Ecol 364:63-71

Ameisen JC (2002) On the origin, evolution, and nature of programmed cell death: a timeline of four billion years. Cell Death Differ 9:367-393

Antonius A (1977) Coral mortality in reefs: a problem for science and management. Proc 3rd Int Coral Reef Symp 2:617-623

Brafield AE, Chapman G (1983) Diffusion of oxygen through the mesogloea of the sea anemone Calliactis parasitica. J Exp Biol 107:181-187

> Cai J, Jones DP (1998) Superoxide in apoptosis. Mitochondrial generation triggered by cytochrome $c$ loss. J Biol Chem 273:11401-11404

Chapman G, Pardy RL (1972) The movement of glucose and glycine through the tissues of Corymorpha palma torrey (Coelenterata, Hydrozoa). J Exp Biol 56:639-645

Dallmeyer DG, Porter JW, Smith GJ (1982) Effects of particu-

Editorial responsibility: Paul Sammarco,

Chauvin, Louisiana, USA late peat on the behavior and physiology of the Jamaican reef-building coral Montastrea annularis. Mar Biol 68: 229-233

Davies PS (1984) The role of zooxanthellae in the nutritional energy requirements of Pocillopora eydouxi. Coral Reefs 2:181-186

Edmunds PJ (2005) Effect of elevated temperature on aerobic respiration of coral recruits. Mar Biol 146:655-663

Gladfelter EH, Michel G, Sanfelici A (1989) Metabolic gradients along a branch of the reef coral Acropora palmata. Bull Mar Sci 44:1166-1173

Kühl M, Cohen Y, Dalsgaard T, Jørgensen BB, Revsbech NP (1995) Microenvironment and photosynthesis of zooxanthellae in scleractinian corals studied with microsensors for $\mathrm{O}_{2}, \mathrm{pH}$ and light. Mar Ecol Prog Ser 117:159-172

Mullen KM, Peters EC, Harvell CD (2004) Coral resistance to disease. In: Rosenberg E, Loya Y (eds) Coral health and disease. Springer-Verlag, Berlin, p 377-399

Muscatine L (1990) The role of symbiotic algae in carbon and energy flux in reef corals. Coral Reefs 25:75-87

Muthiga NA, Szmant AM (1987) The effects of salinity stress on the rates of aerobic respiration and photosynthesis in the hermatypic coral Siderastrea siderea. Biol Bull 173: $539-551$

> Nii CM, Muscatine L (1997) Oxidative stress in the symbiotic sea anemone Aiptasia pulchella (Carlgren, 1943): contribution of the animal to superoxide ion production at elevated temperature. Biol Bull 192:444-456

Revsbech NP, Jørgensen BB (1986) Microelectrodes: their use in microbial ecology. Adv Microb Ecol 9:293-352

> Richardson LL (1998) Coral diseases: What is really known? Trends Ecol Evol 13:438-443

> Roff G, Hoegh-Guldberg O, Fine M (2006) Intra-colonial response to acroporid 'white syndrome' lesions in tabular Acropora spp. (Scleractinia). Coral Reefs 25:255-264

Roff G, Kvennefors ECE, Ulstrup KE, Fine M, Hoegh-Guldberg O (2008) Coral disease physiology: the impact of acroporid white syndrome on Symbiodinium. Coral Reefs 27:373-377

Rosenberg E, Koren O, Reshef L, Efrony R, Zilber-Rosenberg I (2007) The role of microorganisms in coral health, disease and evolution. Nat Rev Microbiol 5:355-362

Stimson J, Kinzie RA (1991) The temporal pattern and rate of release of zooxanthellae from the reef coral Pocillopora damicornis (Linnaeus) under nitrogen enrichment and control conditions. J Exp Mar Biol Ecol 153:63-74

Strychar KB, Sammarco PW (2009) Exaptation in corals to high seawater temperatures: low concentrations of apoptotic and necrotic cells in host coral tissue under bleaching conditions. J Exp Mar Biol Ecol 369:31-42

> Strychar KB, Coates M, Sammarco PW, Piva TJ (2004) Bleaching as a pathogenic response in scleractinian corals, evidenced by high concentrations of apoptotic and necrotic zooxanthellae. J Exp Mar Biol Ecol 304:99-121

> Sussman M, Willis BL, Victor S, Bourne DG (2008) Coral pathogens identified for white syndrome (WS) epizootics in the Indo-Pacific. PLoS ONE 3:e2393

Willis B, Page CA, Dinsdale EA (2004) Coral diseases on the Great Barrier Reef. In: Rosenberg E, Loya Y (eds) Coral health and disease. Springer-Verlag, Berlin, p 69-104

> Work TM, Aeby GS (2006) Systematically describing gross lesions in corals. Dis Aquat Org 70:155-160

Zmasek CM, Zhang Q, Ye Y, Godzik A (2007) Surprising complexity of the ancestral apoptosis network. Genome Biol 8:R226

Submitted: February 2, 2010; Accepted: June 23, 2010

Proofs received from author(s): July 22, 2010 